\title{
Salmonella Minnesota Emergence in Poultry Production: Danger to Public Health?
}

Roberta Torres de Melo ( $\sim$ roberta-melo@hotmail.com )

Universidade Federal de Uberlandia https://orcid.org/0000-0001-8265-5163

Taciano dos Reis Cardoso

Faculdade de Patos de Minas

Phelipe Augusto Borba Martins Peres

Universidade Federal de Uberlandia

\section{Raquelline Figueiredo Braz}

Universidade Federal de Uberlandia - Campus Umuarama

Fernanda Aparecida Longato Santos

Universidade Federal de Uberlandia

Guilherme Paz Monteiro

Universidade Federal de Uberlandia

Daise Aparecida Rossi

Universidade Federal de Uberlandia

Research article

Keywords: broiler, control, gene, PFGE

Posted Date: May 11th, 2020

DOI: https://doi.org/10.21203/rs.3.rs-23509/v1

License: (c) (1) This work is licensed under a Creative Commons Attribution 4.0 International License.

Read Full License 


\section{Abstract}

Purpose: The aim of this study was to analyze in $S$. Minnesota the presence of virulence genes, phylogenetic relationship, biofilm formation index $(\mathrm{BFI})$ and its ultrastructure at temperatures of $4{ }^{\circ} \mathrm{C}$, $25^{\circ} \mathrm{C}$ and $36^{\circ} \mathrm{C}$ and also the ability of biocidal agents to promote inhibition of the sessile structure formed by 20 strains isolated in the years 2009, 2010 and 2014 in broiler slaughter plants of two Brazilian companies.

Methods: The presence of specific genes was evaluated by PCR and the phylogeny between the strains by PFGE, while BFI was performed by the classical method using TSB broth supplemented with $5 \%$ of chiken juice and its structure observed by SEM Chlorhexidine $1 \%$, sodium hypochlorite $1 \%$ and peracetic acid $0.8 \%$ were tested for biofilm inhibition.

Results: The presence of specific genes indicates that $S$. Minnesota has the potential to cause disease in humans and to adapt to adverse conditions. In general, temperatures of $25^{\circ} \mathrm{C}$ and $36^{\circ} \mathrm{C}$ favored more biofilm formation, although at $4{ }^{\circ} \mathrm{C}$ there is still biomass with potential contaminant from the final product. Tolerant strains (12/20-60\%) to all biocides pose a real risk for the development of adaptation mechanisms, especially for resistance to sodium hypochlorite. Phylogenetic analysis indicated the existence of cross contamination problems and the spread among companies, probably related to the formation of biofilms.

Conclusion: The results show the necessity of attention to this serovar considering its resistance to sodium hypochlorite in addition to the need for rigorous monitoring and control measures based on the adoption of low temperatures in order to prevent the formation of biofilms in the poultry industry.

\section{Introduction}

The genus Salmonella comprises a group of pathogenic and zoonotic microorganisms frequently associated with foodborne diseases, having as main source of human infection the ingestion of chicken meat and its derivatives $[13,21]$.

The control of Salmonella in food of animal origin, specifically the chicken meat, is performed by searching the agent in $25 \mathrm{~g}$ of the sample. The presence of the genus Salmonella spp. is already a reason for sanitary embargoes or international warnings due to the compromised meat quality $[22,19,16,43$, 12]. In particular, the $S$. Minnesota species has been gaining prominence among serovars due to the increasing number of isolations in the poultry production chain, prompting research to know its danger as an agent of human salmonellosis. In Brazil, this serovar was the second highest incident between 2007 and 2011 in an investigation of 12,582 strains obtained from chicken carcasses and poultry products [19].

The participation of $S$. Minnesota in human infection and the strategies that this agent uses for its maintenance in the poultry chain is still little known, so there is a need of more studies focused on the 
epidemiological characterization through phylogenetic analysis to understand the spread of the agent. Pulsed Field Gel Electrophoresis (PFGE) subtyping provides information that favors genotypic characterization and molecular grouping, and subsequently the creation of measures for its control [42].

Considering the complexity of Salmonella and host/environment interaction, the investigation of virulence factors and their persistence in the environment via genotypic and phenotypic analysis allows a better understanding of the pathogen. Identify genes associated with apoptosis (avrA), oxidative stress $(\operatorname{sod} C)$, invasion $(\operatorname{inv} A)$, adhesion and biofilm (agfA, sefA and IpfA) and quorum sensing $(\operatorname{IuxS})[15,39,6]$ helps to characterize the pathogenic potential and to understand the strategies for perpetuation in the environment. At the same time, among the hypotheses that may explain $S$. Minnesota persistence in the environment, its ability to form biofilms stands out, which hinders its control in the food industry [46]. In this condition microorganisms have different responses to heat treatments, biocides and antimicrobials, and are therefore a constant source of contamination $[18,27,40]$.

Knowing the emergence of $S$. Minnesota, the aim of this work was to evaluate the presence of virulence and environmental adaptation genes, the ability of biofilm formation under different conditions and to establish the phylogenetic relationship of 20 strains of $S$. Minnesota in order to elucidate the spread, the potential danger that they may represent for human health and possible control measures of the sessile structure.

\section{Results}

\section{Virulence genes characterization}

The 20 strains of $S$. Minnesota showed different frequencies of positivity for the genes studied. Genes linked to apoptosis induction in infected cells (avrA), oxidative stress ( $\operatorname{sod} C$ ) and invasion (invA) were present in $100 \%(20 / 20)$ of the strains. Those linked to adhesion (agfA), potential biofilm-forming capacity (IpfA) and quorum sensing (IuxS) were identified in 95\% (19/20), 75\% (15/20) and 80\% (16/20) of strains, respectively.

The strains were discriminated into four distinct virulence profiles (P1, P2, P3 and P4), being P1 positive for all genes (10/20-50.0\%); P2 negative only for luxS (4/20-20.0\%); P3 negative for IpfA (5/20-25.0\%) and P4 negative for agfA (1/20-5.0\%), Table 1. 
Table 1

S. Minnesota virulence profiles isolated from slaughter plants located in three brazilian states during 2009, 2010 and 2014.

\begin{tabular}{|lll|}
\hline Virulence genes & Profile & $\mathbf{N}(\%)$ \\
\hline avrA, sodC, invA, agfA, IpfA, luxS & P1 & $10(50)$ \\
\hline avrA, sodC, invA, agfA, IpfA & P2 & $4(20)$ \\
\hline avrA, sodC, invA, agfA, IuxS & P3 & $5(25)$ \\
\hline avrA, sodC, invA, IpfA, IuxS & P4 & $1(5)$ \\
\hline Total & & $20(100)$ \\
\hline
\end{tabular}

\section{Biofilm formation $\mathrm{x}$ temperature}

From the 20 strains evaluated, it was observed that all (100\%) were unable to form biofilm at $4{ }^{\circ} \mathrm{C}$, according to the classification by Naves in 2008 [30] (Table 2). 
Table 2

Classification of $S$. Minnesota strains according to Biofilm Formation Index (BFI) at different temperatures.

\begin{tabular}{|c|c|c|c|c|c|c|}
\hline \multirow[t]{2}{*}{ Strains } & \multicolumn{2}{|l|}{$4^{\circ} \mathrm{C}$} & \multicolumn{2}{|l|}{$25^{\circ} \mathrm{C}$} & \multicolumn{2}{|l|}{$36^{\circ} \mathrm{C}$} \\
\hline & $\mathrm{BFI}$ & Classification & BFI & Classification & BFI & Classification \\
\hline M01 & $0.159 *$ & Nonexistent & $0.284^{*}$ & Nonexistent & $0.916^{\star}$ & Medium \\
\hline M02 & $0.144^{\star}$ & Nonexistent & $0.226^{*}$ & Nonexistent & $0.217^{\star}$ & Nonexistent \\
\hline M03 & 0.056 & Nonexistent & $0.175^{\star}$ & Nonexistent & $0.269 *$ & Nonexistent \\
\hline M04 & 0.066 & Nonexistent & $0.891^{*}$ & Medium & $0.539 *$ & Weak \\
\hline M05 & $0.079 *$ & Nonexistent & $0.493^{*}$ & Weak & $0.438^{\star}$ & Weak \\
\hline M06 & $0.162^{\star}$ & Nonexistent & $0.471^{\star}$ & Weak & $0.431^{\star}$ & Weak \\
\hline M07 & $0.118^{*}$ & Nonexistent & $0.550 *$ & Weak & $0.866^{\star}$ & Medium \\
\hline M08 & $0.074^{\star}$ & Nonexistent & $0.870 *$ & Medium & $0.612^{\star}$ & Weak \\
\hline M09 & $0.179 *$ & Nonexistent & $0.928 *$ & Medium & $0.547^{\star}$ & Weak \\
\hline M10 & 0.039 & Nonexistent & $0.229 *$ & Nonexistent & $0.537^{\star}$ & Weak \\
\hline M11 & 0.037 & Nonexistent & 0.039 & Nonexistent & $0.136^{\star}$ & Nonexistent \\
\hline M12 & 0.067 & Nonexistent & $0.517 *$ & Weak & $0.421^{\star}$ & Weak \\
\hline M13 & 0.025 & Nonexistent & $0.284^{\star}$ & Nonexistent & $0.095^{\star}$ & Nonexistent \\
\hline M14 & 0.059 & Nonexistent & $0.179 *$ & Nonexistent & $0.105^{\star}$ & Nonexistent \\
\hline M15 & $0.088^{*}$ & Nonexistent & $0.576^{*}$ & Weak & $0.644^{\star}$ & Weak \\
\hline M16 & 0.039 & Nonexistent & $0.179 *$ & Nonexistent & $0.215^{\star}$ & Nonexistent \\
\hline M17 & 0.056 & Nonexistent & $0.219 *$ & Nonexistent & $0.206^{\star}$ & Nonexistent \\
\hline M18 & $0.077^{*}$ & Nonexistent & $0.173^{*}$ & Nonexistent & $0.196^{\star}$ & Nonexistent \\
\hline M19 & 0.054 & Nonexistent & $0.462^{*}$ & Weak & $0.875^{\star}$ & Medium \\
\hline M20 & 0.030 & Nonexistent & $0.196^{*}$ & Nonexistent & $0.118^{*}$ & Nonexistent \\
\hline
\end{tabular}

The temperature increase $\left(25\right.$ and $\left.36^{\circ} \mathrm{C}\right)$ favored the sessile life form, with formation of weak biofilms $\left(6 / 20\right.$ strains at $25^{\circ} \mathrm{C}$ and $8 / 20$ strains at $\left.36^{\circ} \mathrm{C}\right)$ and medium intensity $\left(3 / 20\right.$ strains at $25^{\circ} \mathrm{C}$ and $\left.36^{\circ} \mathrm{C}\right)$ (Table 2). No strong BFI was identified at any of the temperatures tested. 
Six BFI profiles were identified in the strains (A-F), the most prevalent being those classified as nonexistent at the three temperatures (9/20-45,0\%) (Table 3).Despite the non-existent biofilm classification for all strains when kept at $4^{\circ} \mathrm{C}$, when we considered the statistical analysis compared to the negative control, we found that $9 / 20(45.0 \%)$ strains presented biomass formation at $4{ }^{\circ} \mathrm{C}, 19 / 20$ (95.0\%) at $25^{\circ} \mathrm{C}$ and $100 \%$ at $36^{\circ} \mathrm{C}$ (Table 2 ).

Table 3

Profile of biofilm formation at different temperatures by $20 \mathrm{~S}$. Minnesota strains according to BFI

\begin{tabular}{|c|c|c|c|c|}
\hline \multicolumn{3}{|c|}{ BFI according to temperature } & \multirow[t]{2}{*}{ Profile } & \multirow[t]{2}{*}{$N(\%)$} \\
\hline $4^{\circ} \mathrm{C}$ & $25^{\circ} \mathrm{C}$ & $36^{\circ} \mathrm{C}$ & & \\
\hline Nonexistent & Nonexistent & Nonexistent & $A$ & $9(45.0)$ \\
\hline Nonexistent & Nonexistent & Weak & B & $1(5.0)$ \\
\hline Nonexistent & Nonexistent & Medium & $\mathrm{C}$ & $1(5.0)$ \\
\hline Nonexistent & Weak & Weak & D & $4(20.0)$ \\
\hline Nonexistent & Weak & Medium & E & $2(10.0)$ \\
\hline Nonexistent & Medium & Weak & $\mathrm{F}$ & $3(15.0)$ \\
\hline
\end{tabular}

The evaluation of the formed biomass showed that the temperatures of $25^{\circ} \mathrm{C}$ and $36^{\circ} \mathrm{C}$ favor the formation of $S$. Minnesota biofilms in the same intensity, compared to the temperature of $4{ }^{\circ} \mathrm{C}$ (Fig. 1).However, in Fig. 2 we can observe three examples of $S$. Minnesota strains that exhibited distinct behaviors and therefore different BFI profiles.

\section{Performance of chemical agents in S. Minnesota sessile}

All chemical agents tested, peracetic acid, sodium hypochlorite and chlorhexidine, reduced $S$. Minnesota sessile counts after exposure for 15 minutes. However, significant difference was only observed for peracetic acid and chlorhexidine. For both agents it was observed that, besides reducing the counts, in $8 / 20(40.0 \%)$ strains no growth was observed after the test. Figure 3 illustrates the quantitative results obtained from untreated biofilms, which obtained a mean value of $6.87 \pm 0.38 \mathrm{Log} C F U . \mathrm{mL}^{-1}(p>0.05)$, and from biofilms treated with different products, which showed growth after 15 minutes of contact.

All strains (20/20-100.0\%) showed resistance to sodium hypochlorite $1 \%$, so that the mean count $(6.57 \pm$ $0.55 \mathrm{Log}$ CFU. $\left.\mathrm{mL}^{-1}\right)$ did not differ from that obtained in the control group $(p>0.05)$. The use of peracetic acid and chlorhexidine demonstrated the same efficiency in significantly reducing counts for resistant strains. The mean count after treatments was equivalent to $3.63 \pm 2.84$ and $2.96 \pm 2.55 \mathrm{Log}_{\text {CFU.mL }}{ }^{-1}$, 
respectively. This result indicated an average decrease of 3.24 and 3.91 log cycles, respectively, compared with the control group.

For both agents, the reduction in the number of CFU varied significantly $(p<0.001)$ between tolerant strains. Six chemical resistance profiles were identified, and profile VI 12/20 (60\%) with resistance to all agents (Table 4).

Table 4

Chemical resistance profiles tested on 20 S. Minnesota biofilms

\begin{tabular}{|c|c|c|c|c|}
\hline \multicolumn{3}{|c|}{ Chemical agentes } & Profile & $\mathbf{N}(\%)$ \\
\hline \multicolumn{3}{|l|}{ Hypochlorite } & I & $3(15.0)$ \\
\hline Hypochlorite & AcidPeracetic & & II & $3(15.0)$ \\
\hline Hypochlorite & Chlorhexidine & & III & $2(10.0)$ \\
\hline Hypochlorite & Chlorhexidine & AcidPeracetic & IV & $12(60.0)$ \\
\hline
\end{tabular}

\section{Phylogenetic Analysis}

The dendrogram, constructed from the results of the PFGE, was compared considering the isolation site, the date of collection and the genotypic and phenotypic characteristics evaluated in our study. The similarity analysis of the 20 strains of $S$. Minnesota showed the presence of 14 pulsotypes (A to $N$ ) (Fig. 4), in which three groups, presented genotypic similarities above $80 \%$ : "C", "K" and "M".

\section{Ultrastructure of treated biofilms}

In the SEM test it became evident that the mature biofilm was not characterized when the bacteria are kept at a temperature of $4{ }^{\circ} \mathrm{C}$ (Fig. 5a). As we found in the microbiological test, the biofilm formed under this temperature is of low intensity, demonstrated by being at the beginning of its development process or the occurrence of a possible stagnation in the initial stages, of which we detected only the presence of punctual microcolonies in the field. The temperatures of 25 and $36^{\circ} \mathrm{C}$ allowed the development of dense clusters of bacteria with evident matrix production between the bacteria (Fig. $5 \mathrm{~b}$ ) and in the outermost region (Fig. 5c) providing the necessary protection to the bacterial community.

The group of bacteria was maintained after treatment with the three agents tested, which is consistent with the expression of the phenotype identified in the quantitative assay. The biomass was maintained for the three strains and had similar characteristics between them, the difference being the type of chemical agent used (Fig. 6). Figure 6a illustrates the maintenance of the integral structure of the biofilm without altering the three-dimensional conformation of the biofilm, highlighted by the bacterial 
agglomeration. This pattern was identified in water-treated biofilms for the three strains. The negative control allowed the characterization of the biofilm formed by this serovar, which has a more dense and stable architecture and the presence of a compact coverage along the surface associated with the presence of exchange channels.

The external cover of extracellular matrix was a less evident parameter in bacteria after treatment with sodium hypochlorite (Fig. 6b), but the maintenance of macrocolonies shows the presence of matrix connecting bacteria and the contact surface, showing the characteristic of mature biofilm (Fig. $6 \mathrm{c}$ ). The treatment with peracetic acid (Fig. 6d) and chlorhexidine (Fig. 6e) promoted not only the reduction of the external EPS matrix, but also the weakening of the connection between the bacteria and the greater access of the microorganism to the chemical agent consistent with the reduction logarithmic identified in the counting analyzes. The existence of dispersed groups of bacterial aggregates evidenced the loss of biofilm conformation and cellular viability or biofilms still immature with primary production of extracellular matrix. Part of the bacterial cells showed altered morphology and impaired membrane integrity (Fig. 6f).

\section{Discussion}

\section{Presence of virulence genes}

Our study showed variations in the frequency of virulence genes in $S$. Minnesota strains. However, the detection of avrA, sod $C$ and invA genes was unanimous. For the inv $A$ gene, this pattern was expected by Rowlands in 2014 [38], when analyzing 237 strains of Salmonella spp. isolated from food in Brazil also reported the presence of the invA gene in all strains. Zou in 2012 [47] in a study conducted in North Carolina (USA), from June 2009 to September 2010, found that $99.3 \%$ of $S$. Enteritidis strains isolated from human outbreaks of salmonellosis had the gene. According to Whang in 2009 [44], the invA gene seems to be very conserved in Salmonella spp., which justifies its high occurrence.

In addition to invasiveness, all strains demonstrated survival potential under oxidative stress ( $\operatorname{sod} C$ ) and apoptosis induction in infected cells (avrA). The existence of these virulence mechanisms reinforces the pathogenic potential of strains and, despite the absence of reported cases of salmonellosis by this serovar, demonstrates the possibility of causing disease in humans. Therefore, its isolation in environmental samples, chicken meat and its derivatives may indicate a potential source of transmission of this agent to humans.

Borges in 2013 [6] evaluated 84 strains of $S$. Enteritidis isolated from 1996 to 2010 in the state of Rio Grande do Sul, Brazil, from different avian sources, and observed a similar result to our study, with the presence of the invA and avrA genes in $100 \%$ of the isolates and the IpfA and agfA genes were identified in $99 \%(83 / 84)$ and $96 \%(81 / 84)$ of the isolates, respectively. In 2016, Ahmed [2] also observed similar results in Egypt in 20 isolates of $S$. Typhimurium from chicken, and in 10 isolates of human origin, with 
frequency of $100 \%$ of invA and avrA genes (30/30). They concluded that a high frequency of these genes is observed in serovars potentially causing salmonellosis in humans.

The absence of the sef $A$ gene in the studied strains may be justified according to the study by Amini in 2010 [3], in which they observed that this specific gene is not present in all serovars, being restricted to group D Salmonella, such as Enteritidis, Dublin, Moscow and Blegdon serotypes.

Although not present in all strains, the genetic potential to form biofilms, associated with the presence of agfA, IpfA and luxS genes, was observed in 75\% (15/20) of the strains. The presence of these genes demonstrate that the studied strains are fully capable of adapting to adverse environmental conditions through the acquisition of sessile life form. But the expression of only one of them already allows the initiation of the process of acquiring sessile form. Similar studies with different Salmonella serotypes have shown the presence of the agfA gene in over $91,4 \%$, the IfpA gene in $80.63 \%$ and the three genes together in more than $73.34 \%$ of strains isolated from birds $[7,6,45,28]$.

According to Borges in 2013 [6], the frequency of virulence determinants and the establishment of genetic profiles of isolates can be used to determine more effective control protocols and prevention measures in industries.

\section{Influence of temperature on $S$. Minnesota biofilms}

In addition to genotypic characteristics, it is known that extrinsic factors also directly affect the sessile lifestyle. Among them, the presence of moist, nutrient-poor surfaces and temperature variations, which in poultry production offer the ideal conditions for Salmonella to settle and form biofilms [4].

The absence of biofilms at $4{ }^{\circ} \mathrm{C}$ was defined according to the BFI determination described by Naves in 2008 [30]. These data are in agreement with the work done by Dhakal in 2019 [20], who found optical density values equal to those of the negative control for six Salmonella serovars tested when kept at refrigeration temperature. However, a study conducted with a standard $S$. Minnesota strain showed that this serovar has the capacity to form medium intensity biofilms under in vitro conditions using the traditional methodology [40].

In addition, our study indicates that the BFI classification for this serovar is strain-dependent, and there are probably other factors that determine this variability, such as the presence and expression of genes linked to biofilm formation (agfA, IpfA and $/ u x S$ ), which encodes aggregative fimbriae and the quorum sensing system whose functions are linked to the process of surface fixation and bacterial communication, respectively, facilitating biofilm formation [28]. In our study, all strains had at least one of these genes, indicating the potential for sessile life that was expressed differently and according to external factors and the expression of this potential.

The increase in biofilm intensity was directly related to the increase in temperature. This is consistent with the study by Borges in 2013 [6] in biofilms in S. Heidelberg, S. Typhimurium, S. Agona, S. Infantis, S. 
Brandenburg and $S$. Tennessee at temperatures of $3{ }^{\circ} \mathrm{C}, 12{ }^{\circ} \mathrm{C}, 28^{\circ} \mathrm{C}$ and $37^{\circ} \mathrm{C}$, whose BFIs ranged from nonexistent to moderate.

Considering the presence of biomass identified as statistically different from the negative control, we observed a higher number of strains capable of forming biofilms at different temperatures. Thus, even under thermal stress conditions under low temperatures, $S$. Minnesota is still capable of forming a biomass that allows its viability, presenting potential contaminant.

The results found in our study indicate that $S$. Minnesota can become a difficult problem to control during broiler processing in industry. Considering the high prevalence of the microorganism in Brazilian broiler poultry and slaughterhouses [43], it is possible to suggest its permanence in the industrial environment, even under stress conditions, through the production of biofilm. This information serves as a warning to the poultry industry as an incentive to develop more rigorous and effective control measures for this agent.

The same behavior in relation to the biofilm formation identified at temperatures of $25^{\circ} \mathrm{C}$ and $36^{\circ} \mathrm{C}$ contradicts the results found in the literature, which states that temperatures below the optimal growth temperature and near the environment intensify the biomass production in Salmonella biofilms [41, 35]. According to Cabarkapa in 2015 [11], the factors involved in biofilm production have different responses depending on the bacterial strain and according to the incubation temperature.

Significant differences $(p<0.05)$ in relation to BFI within the same serotype indicate that there is probably influence of intrinsic characteristics, such as the presence of fimbriae, flagella, membrane proteins and others [1], which even present at the molecular level vary in their expression. Thus, environmental conditions alone are not decisive and limiting in the formation of biofilms. Genotypic diversity and the way in which these factors are expressed and determine the phenotype which, in association, influence the production of sessile biomass by $S$. Minnesota should also be considered.

The image analysis allowed to confirm the differences identified in the biofilm according to the temperatures (Fig. 5). The ultrastructure of the biofilm formed by $S$. Minnesota at temperatures of 25 and $36^{\circ} \mathrm{C}$ showed a more stable and mature conformational characteristic compared to the temperature of 4 ${ }^{\circ} \mathrm{C}$ consistent with that found in different Salmonella serovars [40].

\section{Chemical agents reduced $S$. Minnesota biofilm}

Peracetic acid, sodium hypochlorite and chlorhexidine are chemical agents widely used in the cleaning of slaughterhouses, including the industry where strains have been isolated. These biocides promoted a reduction in $S$. Minnesota biofilm counts after exposure for 15 minutes. However, the use of peracetic acid and chlorhexidine demonstrated the same efficiency in significantly reducing counts for resistant strains, differently of what was observed for sodium hypochlorite, which in all strains showed resistance. 
This is alarming because sodium hypochlorite is one of the most widely used cleaning and disinfecting agents in the industry.

The presence of strains tolerant to different sanitizers suggests that the inappropriate use of these agents in the routine of the industrial environment may result from sublethal exposure to these biocides, representing a real risk to the resistance and adaptation of these bacteria, besides favoring the production of biofilms [24], since under these conditions the adaptive response mechanisms of stress bacteria are activated, promoting their survival even in harsh environments [33].

Regarding the high resistance observed to sodium hypochlorite, it is also possible to associate the involvement of molecular factors, such as RpoS, Dps and sodC genes, linked to oxidative stress, being the last one identified in all strains of our study. These genes are actively expressed in S. Enteritidis SE86, resistant to the presence of sodium hypochlorite at $200 \mathrm{ppm}$ [37]. It is also possible that for $S$. Minnesota there are similar mechanisms at work in this process. In addition, the properties of this sanitizer can be altered according to the $\mathrm{pH}$ variation and the presence of organic matter that alternate the availability of hypochlorous acid, reducing its efficiency [34].

The variation in the counts for the different strains identified after contact with peracetic acid and chlorhexidine demonstrated that the persistence of the presence of these microorganisms may be a strain-dependent characteristic.

The existence of strains with resistance profile to all agents (profile IV) (Table 4) (12/20-60\%) indicates that there are probably intrinsic or extrinsic adaptive mechanisms that allow their survival. This fact may characterize a potential risk in industry due to the difficulty in eliminating these microorganisms and the risk of spreading this characteristic to other bacterial strains.

Although the use of chemical compounds brings benefits in the disinfection stage, these agents usually have the limitation of not destroying the residual structures of the bacterial biofilm matrix, which can facilitate the resurgence or even the maintenance of these structures on the surfaces [32]. In our study, we observed that the external matrix was maintained only when the strains were treated with sodium hypochlorite. Therefore, bacterial resistance seems to be related to the limitation of the presence of organic matter and, for this case, special efforts are required for the complete removal of $S$. Minnesota biofilms adapted to this biocide. Probably, the effectiveness in controlling these microorganisms will be achieved through sanitation plans that combine cleaning measures focused on the elimination of the extrapolymeric matrix combined with the use of different agents and on the periodic rotation of disinfectants, respecting the periods between disinfections.

In a different way, peracetic acid and chlorhexidine proved to be effective in eliminating the external matrix and in disrupting the conformation of mature biofilm. This profile may be associated with the mechanism of action aimed at the denaturation of proteins, cellular enzymes, increased permeability of the bacterial cell and cell lysis [5]. 


\section{Similarity between strains}

Phylogenetic analysis identified strains with distinct molecular profiles. Only pulsotypes $\mathrm{C}, \mathrm{K}$ and $\mathrm{M}$ grouped strains that allowed an epidemiological evaluation. Pulsotype "C" grouped two strains, M17 and M14, with similarity of $82.8 \%$, coming from the industry B broiler poultry in different periods, 2009 and 2010 , with the presence of $\operatorname{avr}$, sodC, invA, agfA and luxS genes in common. Although they belong to the same industry (B), they are strains of distinct flocks; one from the state of São Paulo and one from Mato Grosso do Sul, indicative of a possible dissemination of this profile, possibly influenced by transport. In addition, the strains behavior in biofilm tests was identical with resistance to the three chemical agents evaluated in sessile form.

The pulsotype "K" grouped four strains, two (M04 and M03) clones isolated from the slaughterhouse of industry A, located in the state of Minas Gerais. Cross-contamination may be the reason for the occurrence of this profile, since they were isolated in very close periods, both dated in November 2014. The presence of avrA, sodC, invA, agfA and IpfA genes was common in both.

Other strains of the K (M20 and M16) pulsotypes were isolated in 2010; both in the aviary and in the industry B, cutting room in Mato Grosso do Sul. The avrA, sodC, invA and luxS genes and resistance to sodium hypochlorite and peracetic acid in biofilms were common among these strains. These data indicates that the maintenance of these microorganisms in sessile form and contamination of the final product may be caused by cross contamination between utensils and the slaughtering environment itself [8].

In addition to cross contamination, there are also signs of neglect of biosecurity standards due to the presence of the agent in clean and dirty areas of processing. According to Moura in 2014 [29], this oversight is decisive for the maintenance of the microorganism in the environment. At the same time, the pulsotype $\mathrm{K}$ indicates that there was a spread of this profile, since there are similar strains in both Mato Grosso do Sul and Minas Gerais, in different slaughter units.

The "M" pulsotype grouped three strains (M08; M07 and M05) with similarity equal to $83,6 \%$ of 2014 , coming from industry A slaughterhouse in the state of Minas Gerais. The strains presented the avrA, sodC, invA and agfA genes in common.

In addition to cross contamination, it is possible to suggest that strains with homology greater than $80 \%$ persist in both the poultry and slaughterhouse environment, probably due to the presence of biofilms, which, even if identified at low intensities in our assays, demonstrated the viability of the strains sessile bacteria at high counts, even in the presence of biocidal agents.

The sessile life form probably caused this serovar to be isolated at different times, as well as facilitating its spread among the different industry environments.

\section{Conclusions}


The presence of virulence, biofilm formation and oxidative stress survival genes in S. Minnesota strains indicates that this serovar has the potential to cause disease in humans and adapt to adverse conditions.

In general, temperatures of $25^{\circ} \mathrm{C}$ and $36^{\circ} \mathrm{C}$ favored the formation of biofilms with higher intensity than those found at $4{ }^{\circ} \mathrm{C}$, where $S$. Minnesota inhibits biofilm formation, but biomass formation is still present potential contaminant of the final product.

The existence of tested biocide tolerant strains suggests a possible exaggerated expression of genes related to oxidative stress and/or the existence of exposure to sublethal concentrations in the environment, posing a real risk for the development of adaptation mechanisms, especially for hypochlorite resistance sodium.

Phylogenetic analysis has shown that strains have high genetic diversity and that the presence of similar strains is probably associated with cross-contamination problems and spread among companies, both related to biofilm formation.

The emergence of serovar combined with the identified genotypic and phenotypic characteristics undoubtedly indicate the need for special attention to serovar in broiler production, aiming at preventing its presence, especially through stricter measures to prevent installation and ensure removal biofilms, allied to monitoring protocols.

\section{Methods}

\section{Samples and Sampling}

Twenty S. Minnesota strains isolated from 2009, 2010 and 2014 were used, originated from broiler slaughtering plants of two Brazilian companies (A and B), with complete production cycle and integration system inspected by the Federal Inspection Service (SIF), qualified for internal and external trade.

From company A, located in the state of Minas Gerais, nine isolates were used and from industry B, with slaughtering plants in the states of São Paulo and Mato Grosso do Sul, seven and four isolates were used, respectively.

Isolations were performed in industrial laboratories, with samples collected at points previously established in internal control programs and/or required by the PRP-Pathogen Reduction Program [9]. The strains were assigned to the study after biochemical identification, as recommended by Normative Instruction 62 [9] and serological (Oswaldo Cruz Institute Foundation in the State of Rio de Janeiro (IOC/FIOCRUZ, Rio de Janeiro, Brazil), and were stored in the library from the Applied Animal Biotechnology Laboratory of the Federal University of Uberlândia (LABIO/UFU, Minas Gerais, Brazil).

\section{Reactivation of strains and extraction of genomic DNA}


The strains were obtained from pure cultures maintained on NA (nutrient agar - OXOID ${ }^{\circledR}$, Roskilde, Denmark) and reactivated in BHI broth (brain heart infusion - OXOID ${ }^{\circledR}$ ) followed by subculturing on TSA Agar (tryptone soybean agar - OXOID $\AA$ ), respecting the conditions of incubation at $37^{\circ} \mathrm{C}$ for 24 hours.

Bacterial suspension obtained in TSB broth (tryptone soyl broth - OXOID $®$ ) overnight was used for the extraction of genomic DNA using the Wizard $\AA$ Genomic DNA Purification commercial kit (Promega ${ }^{\circledR}$, Wisconsin, United States), following a protocol provided by the manufacturer.

\section{Identification of specific genes}

Conventional PCR was used to identify genes linked to the apoptosis process (avrA), potential survival under oxidative stress ( $\operatorname{sod} C$ ), invasion (invA), adhesion and biofilm formation (agfA, $\operatorname{sef} A$ and $\operatorname{Ipf} A$ ) and quorum-sensing (IuxS) as described in Table 5.

Table 5

Primers used to identify specific genes in S. Minnesota strains.

\begin{tabular}{|c|c|c|c|c|}
\hline Gene & Concentration & $\begin{array}{l}\text { Amplicon } \\
\text { (bp)* }\end{array}$ & Primer & Reference \\
\hline \multirow[t]{2}{*}{ avrA } & \multirow[t]{2}{*}{$20 \mathrm{pmol}$} & \multirow[t]{2}{*}{385} & GTTATGGACGGAACGACATCGG & \multirow{2}{*}{$\begin{array}{l}\text { Prager et al. } \\
(2003)\end{array}$} \\
\hline & & & ATTCTGCTTCCCGCCGCC & \\
\hline \multirow[t]{2}{*}{ sodC } & \multirow[t]{2}{*}{$20 \mathrm{pmol}$} & \multirow[t]{2}{*}{500} & ATGAAGCGATTAAGTTTAGCGATGG & \multirow{2}{*}{$\begin{array}{l}\text { Sanjayet al. } \\
(2010)\end{array}$} \\
\hline & & & TTTAATGACTCCGCAGGCGTAACGC & \\
\hline \multirow[t]{2}{*}{$\operatorname{inv} A$} & \multirow[t]{2}{*}{$10 \mathrm{pmol}$} & \multirow[t]{2}{*}{284} & GTGAAATTATCGCCACGTTCGGGCAA & \multirow{2}{*}{$\begin{array}{l}\text { Oliveira et al. } \\
\text { (2002) }\end{array}$} \\
\hline & & & TCATCGCACCGTCAAAGGAACC & \\
\hline \multirow[t]{2}{*}{ sefA } & \multirow[t]{2}{*}{$10 \mathrm{pmol}$} & \multirow[t]{2}{*}{488} & GATACTGCTGAACGTAGAAGG & \multirow{2}{*}{$\begin{array}{l}\text { Oliveira et al. } \\
\text { (2002) }\end{array}$} \\
\hline & & & GCGTAAATCAGGATCTGCAGTAGC & \\
\hline \multirow[t]{2}{*}{$\operatorname{agfA}$} & \multirow[t]{2}{*}{$10 \mathrm{pmol}$} & \multirow[t]{2}{*}{350} & TCCACAATGGGGCGGCGGCG & \multirow{2}{*}{$\begin{array}{l}\text { Collinson et al. } \\
\text { (1993) }\end{array}$} \\
\hline & & & CCTGACGCACCATTACGCTG & \\
\hline \multirow[t]{2}{*}{ IpfA } & \multirow[t]{2}{*}{$10 \mathrm{pmol}$} & \multirow[t]{2}{*}{250} & CTTTCGCTGCTGAATCTGGT & \multirow{2}{*}{$\begin{array}{l}\text { Heuzenroeder et } \\
\text { al. (2000) }\end{array}$} \\
\hline & & & CAGTGTTAACAGAAACCAGT & \\
\hline \multirow[t]{2}{*}{ luxS } & \multirow[t]{2}{*}{$20 \mathrm{pmol}$} & \multirow[t]{2}{*}{1080} & GATAATCCTGAACTAAGCTTCTCCGC & \multirow{2}{*}{$\begin{array}{l}\text { Choi j et al. } \\
\text { (2007) }\end{array}$} \\
\hline & & & GGTTATGAGAAAAGCATGCACCGATCA & \\
\hline
\end{tabular}


The PCR reaction preparation consisted of $12.5 \mu \mathrm{L}$ of GoTaq ${ }^{\circledR}$ Green Master Mix (Promega $\left.{ }^{\circledR}\right), 1 \mu \mathrm{L}$ of DNA at $10 \mathrm{ng} / \mu \mathrm{L}, 1 \mu \mathrm{L}$ of the gene-specific primer pairs (Table 5 ) and $10.5 \mu \mathrm{L}$ of Milli-Q® Water (Merck ${ }^{\circledR}$, Darmstadt, Germany). The microtubes were transferred to the thermal cycler (Eppendorf®, Hamburg, Germany) for amplification according to the cycles: an initial denaturation cycle at $94{ }^{\circ} \mathrm{C}$ for 5 minutes, 35 cycles of denaturation at $94^{\circ} \mathrm{C}$ for 45 seconds, annealing for 30 seconds at $58^{\circ} \mathrm{C}($ invA); at $50^{\circ} \mathrm{C}$ (sefA and $\left.1 p f A\right)$, at $66^{\circ} \mathrm{C}$ (agfA) and $62^{\circ} \mathrm{C}$ (avrA, sodC and luxS); extension at $72^{\circ} \mathrm{C}$ for 90 seconds, with a final extension at $72{ }^{\circ} \mathrm{C}$ for 10 minutes. The positive reaction control used was the strain $S$. Enteritidis ATCC 13076 and, as negative control, sterile ultrapure water.

Amplified products $(8 \mu \mathrm{L})$ were submitted to $1.5 \%$ agarose gel electrophoresis using the $0.5 \mathrm{x}$ TBE running buffer (Invitrogen ${ }^{\circledR}$, California, United States) and the 100 bp marker (Invitrogen ${ }^{\circledR}$ ) as the molecular weight standard. Agarose gels (Afllymetrix ${ }^{\circledR}$, California, United States) were stained with SYBR® Safe DNA gel stain solution (Invitrogen $®$ ) and visualized under UV light on the transilluminator (Loccus Biotechnology ${ }^{\circledR}$, São Paulo, Brazil) after 90 minutes of running the gel at $100 \mathrm{~W}$ of power, $80 \mathrm{~V}$ of voltage and $80 \mathrm{~A}$ of electric current.

\section{Pulsed-Field Gel Electrophoresis (PFGE)}

The Pulse Net protocol, recommended by the CDC in 2013 [14] was used. Bacteria grown at $37^{\circ} \mathrm{C}$ overnight on TSA agar $(O X O I D \otimes)$ were suspended in tubes containing $2 \mathrm{~mL}$ of phosphate buffered saline (PBS: $0.01 \mathrm{M}$ phosphate buffer; $\mathrm{pH} 7.2 ; 0.85 \% \mathrm{NaCl}$ ). After agarose blocking, genomic DNA digestion was performed with $30 \mathrm{U}$ of Xba I enzyme (Invitrogen ${ }^{\circledR}$ ) for two hours at $25^{\circ} \mathrm{C}$.

The DNA fragments were separated on $1 \%$ agarose gel (SeaKem Gold $\circledast$ ) in 0.5X TBE buffer in CHEF DRIII (Bio-Rad ${ }^{\circledR}$, California, United States) for a period of 18 hours with the following parameters: $200 \mathrm{v}, 120^{\circ}$ angle, $6 \mathrm{v} / \mathrm{cm}$ gradient and $14{ }^{\circ} \mathrm{C}$ buffer temperature. The gels were stained with ethidium bromide, photographed under UV light in a transilluminator (Loccus Biotechnology ${ }^{\circledR}$ ) and evaluated using the GelCompar II program.

\section{Biofilm Formation Index}

The determination of biofilm formation index (BFI) was performed according to Kudirkienein 2012 [25] and Naves in 2008 [30], with modifications. The strains were cultivated in TSB broth (OXOID $\left.{ }^{8}\right)$ supplemented with $5 \%$ of chicken juice to simulate nutritional stress in a slaughterhouse environment. Incubation was performed for 24 hours at $37^{\circ} \mathrm{C}$ under constant agitation $(175 \mathrm{rpm})$ until reaching $\mathrm{OD}_{600}$ close to 0,25 . The suspension was centrifuged at $5000 \mathrm{rpm} / 10 \mathrm{~min} / 4^{\circ} \mathrm{C}$, and the pellet obtained was washed with $0.9 \% \mathrm{NaCl}$ solution in three successive centrifugations. The last wash suspension was added to the TSB broth (OXOID $®)$ supplemented with $5 \%$ of chicken juice at a 1:100 concentration, which was then added to a polystyrene microplate (Kasvi®, Paraná, Brazil) and incubated for 24 hours at the three pre-set temperatures determined at $4^{\circ} \mathrm{C}, 25^{\circ} \mathrm{C}$ and $36^{\circ} \mathrm{C}$. As control the strain of Salmonella 
Enteritidis ATCC13076 was used. Three repetitions were performed with eight replicates for each of the temperatures.

The biofilm formed at the bottom of the wells was washed twice with $0.9 \% \mathrm{NaCl}$ solution and dried at $55^{\circ} \mathrm{C}$ for 50 minutes. After drying, $200 \mu \mathrm{L}$ of $1 \%$ crystal violet solution (Synth ${ }^{\circledR}$, São Paulo, Brazil) was added to each well for 5 minutes. The plates were then washed three times with ultrapure water and dried again at $55^{\circ} \mathrm{C}$ for 15 minutes, then eluting the dye with methyl alcohol solution (Synth $\AA$ ) and reading the absorbance at $\mathrm{OD}_{600}$. Results from suspended cells and adhered cells were tabulated to determine Biofilm Formation Index (BFI) using the formula: $B F I=A B-P C / S B$.

$\mathrm{BFI}$ is the result of the detected index, $\mathrm{AB}$ the reading of adherent bacteria, $\mathrm{PC}$ the absorbance reading of the control wells without microorganisms and SB the absorbance reading of the suspended bacteria. They were classified as strong if $\geq 1.10$, medium: $0.70-1.10$, weak: $0.36-0.69$ or nonexistent if $\leq 0.35$.

\section{Biofilm Formation Inhibition Test}

The assay was performed according to the protocol described by Lu in 2012 [26]. The biofilm formation was performed from a $100 \mu \mathrm{L}$ of inoculum containing $10^{7} \mathrm{CFU} / \mathrm{mL}$ of the bacteria on four cellulose membranes placed in TSA (OXOID $\left.{ }^{\circledR}\right)$ agar plates incubated at $36^{\circ} \mathrm{C}$ for 24 hours.

After incubation, the membranes were removed and transferred back to a new TSA agar plate (OXOID $®)$, incubated under the same conditions and again repeated after 24 hours. On the third day the membranes were added to the sterile vial treatments, the first being the TSB broth control, the second with $1 \%$ chlorhexidine (Vicpharma ${ }^{\circledR}$, São Paulo, Brazil), the third with sodium hypochlorite 1\% (Sanikoll ${ }^{\circledR}$, São Paulo, Brazil) and the fourth with 0,8\% peracetic acid (Synth $\left.{ }^{\circledR}\right)$. Each treatment was incubated for 15 minutes at room temperature. The membranes were washed with saline solution and after washing $1 \%$ trypsin solution (ThermoFisher ${ }^{\circledR}$, Massachusetts, United States) was added and maintained for 15 minutes. Serial dilutions of the detached content were made to dilution $10^{-6}$, which was then added to TSA plates incubated at $36^{\circ} \mathrm{C}$ for 24 hours to perform counts.

\section{Scanning electron microscopy}

Confirmation of the phenotype obtained in the biofilm formation assays, three selected strains that showed resistance to the three chemical agents tested were evaluated for the ultrastructure formed at temperatures of 4,25 and $36^{\circ} \mathrm{C}$ and, separately, in treatments with sodium hypochlorite at $1 \%, 1 \%$ chlorhexidine and $1 \%$ peracetic acid after the production of the sessile structure at $36^{\circ} \mathrm{C}$. The assays were performed by Scanning Electron Microscopy.

The preparation of the material for SEM analysis was done according to Brown et al. (2014) [10], with modifications. Biofilms were formed in $5 \mathrm{~mm}$ diameter glass beads, respecting the growth conditions 
described above. After biomass formation, the biofilms biofilms were treated for 15 minutes as mentioned in the previous topic. The samples were fixed with $72.5 \%$ of glutaraldehyde and $2.5 \%$ of paraformaldehyde in $0.1 \mathrm{M}$ PBS buffer $(\mathrm{pH} 7.4)$ overnight at $4{ }^{\circ} \mathrm{C}$. The fixative was removed, and the samples washed three times with PBS buffer. The beads were post fixed with $1 \%$ of osmium tethoxide for two hours and washed three times with PBS buffer. The beads were dehydrated in a series of ethanol solutions $(30,40,50,60,70,80$ and $90 \%$ and then three times at $100 \%)$ for 15 minutes for each step.

Samples were dried on CPD (Critical Drying Point) (CPD 030, Baltec ${ }^{\circledR}$, Liechtenstein, Deutsch) using liquid carbon dioxide as the transition fluid, then coated with a $20 \mathrm{~nm}$ of gold layer (SCD 050, Baltec ${ }^{\circledR}$ ) and displayed on SEM Zeiss Supra 55 FEG SEM operating at $20 \mathrm{kV}$.

\section{Analysis of Results}

The virulence gene results were analyzed using descriptive statistics, with calculation of percentages. The analysis for dendrogram construction was performed using GelCompar II software. The comparison of the band patterns was performed by the UPGMA analysis method, using the Dice similarity coefficient, with a tolerance of $1.5 \%$ in the comparison of the position of the bands.

The interpretation of data related to biofilms was done using the GraphPadPrism software ${ }^{\circledR}$, version 7.0. Simple analysis of variance test (ANOVA) was applied for qualitative and quantitative biofilm formation tests and for comparison between treatments. For the biofilm inhibition test, a nonparametric KruskalWallis test was used. For all tests a $95 \%$ of confidence interval was used.

\section{Declarations}

\section{Ethics approval and consent to participate}

Not applicable

\section{Consent for publication}

Not applicable

\section{Availability of data and materials}

Not applicable

\section{Competing interests}

The authors declare no competing interests. 


\section{Funding}

This study was financed in part by the Coordination for the Improvement of Higher Education Personnel Brazil (CAPES), Minas Gerais State Research Support Foundation (FAPEMIG) and National Council for Scientific and Technological Development (CNPq) - Finance Code 001 .

\section{Autohrs' contribuitions}

Melo RT and Rossi AP planned and developed the project. Melo RT and Cardoso TR analysed, interpreted the data and wrote the manuscript. Monteiro GP and Peres PABM performed microbiological, and molecular analyses. Braz RF and Santos FAL contributed to the scanning electron microscopy analyses, writing of the article and with submission process.

\section{Aknowledgements}

Coordination for the Improvement of Higher Education Personnel - Brazil (CAPES), Minas Gerais State Research Support Foundation (FAPEMIG) and National Council for Scientific and Technological Development (CNPq), for their financial support.

\section{Authors' information}

${ }^{1}$ Laboratory of Molecular Epidemiology (LEPIMOL), School of Veterinary Medicine, Federal University of Uberlandia, Uberlandia, MG, Brazil.Av. Ceara s/n, BI. 2D, R. 48, Campus Umuarama, CEP: 38400902,Uberlândia-MG, Brazil. Phone: +55 (34)3213- 2319.

\section{References}

1. Agarwal RK, Singh S, Bhilegaonkar KN, Singh VP. Optimization of microtitre plate assay for the testing of biofilm formation ability in different Salmonella serotypes. Int Food Res J. 2011; 18(4): 1493-1498.

2. Ahmed HA, El-Hofy FI, Shafik SM, Abdelrahman MA, Elsaid GA. Characterization of virulenceassociated genes, antimicrobial resistance genes, and class 1 integrons in Salmonella enteric sorovarTyphimurium isolates from chicken meat and humans in Egypt. FoodbornePathogDis. 2016; 13(6):281-288.

3. Amini K, Salehi TZ, Nikbahkht G, Ranjbar R, Amini J, Ashrafganjooei SB. Molecular detection of invA and spv virulence genes in Salmonella Enteritidis isolated from human and animals in Iran.Afr J Microbiol Res. 2010; 4(21):2202-2210.

4. Ariafar MN, Buzrul S, Akçelik N. Modeling and predicting the biofilm formation of Salmonella Virchow with respect to temperature and pH.ActaBiol Hung. 2016; 67(1):99-111. 
5. Barah F. Non-antibiotic Biocides: An updated review. In: Méndez-Vilas A, editor. Microbial pathogens and strategies for combating them: Science, technology and education. Spain: Formatex Research Centre; 2013. p. 598-607.

6. Borges KA, Furian TQ, Borsoi A, Moraes HLS, Salle CTP, Nascimento VP. Detection of virulenceassociated genes in Salmonella Enteritidis isolates from chicken in Southern Brazil. Pesq Vet Bras. 2013; 33(12):1416-1422.

7. Borsoi A, Santin E, Santos LR, Salle CTP, Moraes HLS, Nascimento VP. Inoculation of newly hatched broiler chicks with two Brazilian isolates of Salmonella Heidelberg strains with different virulence gene profile, antimicrobial resistance and pulsed field gel electrophoresis pattern to intestinal changes evaluation. PoultSci. 2009; 88(4):750-8.

8. Brasão SC. Biofilmes de Salmonella Minnesota: Formação, Influência da Superfície, Inibição por Agentes Químicos e Importância do Período entre Tratamentos.https://repositorio.ufu.br/handle/123456789/21131 (2017). Accessed 10 Nov 2019.

9. Brasil. MAPA Ministério da Agricultura, Pecuária e Abastecimento. Instrução Normativa $N^{0} 70$, de 06 de outubro de 2003: Institui o Programa de Redução de Patógenos - Monitoramento Microbiológico e Controle de Salmonella sp. em carcaças de Frangos e Perus.http://www.agricultura.gov.br/assuntos/inspecao/produtos-animal/controle-de patogenos/salmonella (2003). Accessed 15 Oct 2019.

10. Brown HL, Reuter M, Salt LJ, Cross K L, Betts RP, van Vliet AH. Chicken juice enhances surface attachment and biofilm formation of Campylobacter jejuni. Appl Environ Microbiol. 2014; 80(22): 7053-7060.

11. Cabarkapal,SkrinjarM, LevicJ, KokicB, BlagojevN, MilanovD, SuvajdzicL.Biofilm forming ability of Salmonella Enteritidis in vitro. Acta VetBeogr. 2015; 65(3): 371-389.

12. Campos J,Mourão J,Silveira L,Saraiva M, CorreiaCB, Maçãs AP, Peixe L,Antunes P.Imported poultry meat as a source of extended-spectrum cephalosporin-resistant CMY-2 producing Salmonella Heidelberg and Salmonella Minnesota in the European Union, 2014-2015.Int. J. Antimicrob. 2018;51(1): 151-154.

13. CDC Centers for Disease Control and Prevention. Emerging and Zoonotic Infectious Diseases.https://www.cdc.gov/ncezid/what-we-do/our-topics.html (2017). Accessed 12 Oct 2019.

14. CDC Centers for Disease Control and Prevention.Standard operating procedure for PulseNet PFGE of Listeria monocytogenes. http://www.cdc.gov/pulsenet/pdf/listeria-pfge-protocol-508c.pdf (2013). Accessed 10 Oct 2019.

15. Choi J, Dongwoo S, Sangryeol R. Implication of quorum sensing in Salmonella enterica serovar Typhimurium virulence: the luxS gene is necessary for expression of genes in pathogenicity island 1 . InfectImmun. 2007; 75(10): 4885-90.

16. CODA-CERVA Centrum voorOnderzoek in DiergeneeskundeenAgrochemie. Centre d'Etudeet des RecherchesVétérinairesetAgrochimiques:SalmonellaSerotypesAnalysedat the CODA-CERVA in 2013. http://www.coda-cerva.be (2014). Accessed 19 Oct 2019. 
17. Collinson K, Doig PC, Doran JL, Clouthier S, Trust TJ, Kay WW. Thin aggregative fimbriae mediate binding of Salmonella Enteritidis to fibronectin. J. Bacteriol. 1993; 175(1):12-18.

18. Corcoran M, Morris D, De Lappe N, O'connor J, Lalor P, Dockery P, et al. Commonly used disinfectants fail to eradicate Salmonella enterica biofilms fromfood contact surface materials. ApplEnvironMicrobiol. 2014; 80(4):1507-1514.

19. Costa RG, Festivo ML, Araujo MS, Reis EM, Lázaro NS, Rodrigues DP. Antimicrobial susceptibility and serovars of Salmonella circulating in comercial poultry carcasses and poultry products in Brazil. J F Prot.2013; 76(12):2011-2017.

20. Dhakal JAL, Sharma CS, Nannapaneni R, McDaniel CD, Kim T, Kiess A. Effect of Chlorine-Induced Sublethal Oxidative Stress on the Biofilm-Forming Ability of Salmonella at Different Temperatures, Nutrient Conditions, and Substrates. J F Prot. 2019; 82(1):78-92.

21. EFSA European Food Safety Authority \& European Centre for Disease Prevention and Control. The European Union Summary report on trends and sources of zoonoses, zoonotic agents and foodborne outbreaks in 2016. EFSA J. 2017. https://www.efsa.europa.eu/en/efsajournal/pub/5077. Accessed 29 Oct 2019.

22. Freitas Neto OC, Penha Filho RAC, Barrow P, Berchieri Junior A. Sources of human non-typhoid salmonellosis: a review. RevBrasCienc Avic. 2010; 12(1): 1-11.

23. Heuzenroeder MW, Murray CJ, Dalcin RM. Molecular basis of benign colonization of Salmonella Sofia in chickens. 2001.https://www.agrifutures.com.au/wp-content/uploads/publications/01106.pdf.Accessed 30 Oct 2019.

24. Keeratipibul S, Techaruwichit P. Tracking sources of Listeria contamination in a cooked chicken meat factory by PCRRAPD-based DNA fingerprinting. Food Control. 2012; 27(1):64-72.

25. Kudirkiene E, Cohn MT, Stabler RA, Strong PCR, Serniene L, Wren BW, Nielsen EM, Malakauskas M, Brondsted L. Phenotypic and genotypic characterizations of Campylobacter jejuni isolated from the broiler meat production process. CurrMicrobiol. 2012; 65(4):398-406.

26. Lu X, Samuelson DR, Rasco BA, Konkel ME. Elucidation of the antimicrobial effect of diallyl sulfide on Campylobacter jejuni biofilms. J AntimicrobChemother. 2012; 67(8):1915-1926.

27. Machado SCA, Pereira VLA, Aquino MHC, Santos AFM, Rodrigues DP, Giombelli A, Nascimento ER. Serotyping and Genotyping of Salmonella Strains Isolated from Broilers, Chicken Carcasses Before and After Chilling, and Frozen Chicken Breasts Produced in the States of Mato Grosso do Sul and Santa Catarina, Brazil. RevBrasCienc Avic. 2017; 19(1):135-142.

28. Melo RT, Ribeiro A, Mendonça EP, Nalevaiko PC, Monteiro GP, Buiatte ABG, Rossi DA. Salmonella Minnesota poultry origin have virulence factors and potential risk to human. ArqBrasMedVet Zootec. 2019.No prelo

29. Moura MS, Oliveira RP, Melo RT, Mendonça EP, Fonseca BB, Rossi DA. Genes de virulência e diversidade genética em Salmonellaspp. isoladas de amostras de origem suína. ArqBrasMedVet Zootec. 2014; 66(5):1367-1375. 
30. Naves P, Del Prado G, Huelves L, Gracia M, Ruiz V, Blanco J.

Measurementofbiofilmformationbyclinicalisolatesof Escherichia coli ismethod-dependent. J Appl Microbiol. 2008; 105(2): 585-590.

31. Oliveira SD, Santos LR, Schucha DMT, Silva AB, Salle CTP, Canal CW. 2002. Detection and identification of salmonellas from poultry-related samples by PCR. Vet Microbiol. 2002; 87(1):25-35.

32. OhsumiT, TakenakaS, Wakamatsu R, SakaueY, NarisawaN, SenpukuH, OkijiT. Residual structure of Streptococcus mutans biofilm following complete disinfection favors secondary bacterial adhesion and biofilm re-development. PLoSOne. 2015;10(1):e0116647.

33. Pereira AA. Estudo da atividade bactericida de óleos essenciais sobre células planctônicas e sésseis de Salmonella spp. http://repositorio.ufla.br/jspui/handle/1/2642 (2014). Accessed 25 Oct 2019.

34. Pfuntner A. Sanitizers and Disinfectants: The Chemicals of Prevention. Food Safety Magazine. 2011. http://www.foodsafetymagazine.com/magazine-archive1/augustseptember-2011/ sanitizers-anddisinfectants-the-chemicals-of-prevention/. Accessed 30 Oct 2019.

35. PirasF, FoisF, ConsolatiSG, MazzaR, MazzetteR. Influence of temperature, source, and serotype on biofilm formation of Salmonella enterica isolates from pig slaughterhouses. J Food Prot. 2015; 78(10):1875-1878.

36. Prager R, Rabsch W, Streckel W, Voigt W, Tietze E, Tschäpe H. Molecular properties of Salmonella enterica serovar Paratyphi B distinguish between its systemic and its enteric pathovars. J. Clin Microbiol. 2003; 41(9):4270-8.

37. Ritter AC, Bacciu D, Santi L, Silva WO, Vainstein MH, Rubino S, Uzzau S, Tondo EC. Investigation of rpoS and dps genes in sodium hypochlorite resistance of Salmonella Enteritidis SE86 isolated from foodborne illness outbreaks in southern Brazil. J Food Prot. 2012; 75(3):437-442.

38. Rowlands REG, Ristori CA, Ikuno AA, Barbosa ML, Jakabi M, Franco BDGM. Prevalence of drug resistance and virulence features in Salmonella spp. isolated from foods associated or not with salmonellosis in Brazil.RevInstMedTrop São Paulo. 2014; 56(6):461-467.

39. Sanjay MK, Shrideshikan SM, Usha MS, Philipraj A, Gaddad SM, Shivannavar CT. Detection, amplification and sequence homology of sodCin clinical isolates of Salmonella sp. Indian J Med Res. 2010; 131:565-570.

40. Silva PLAPA, Goulart LR, Reis TFM, Mendonça EP, Melo RT, Penha VAS, Peres PABM, Hoepers PG, Beletti ME, Fonseca BB. Biofilm Formation in Different Salmonella Serotypes Isolated from Poultry. Curr Microbiol. 2018; 76(1):124-129.

41. Stepanović S, Ćirković I, Mijać V, Švabić-Vlahović M. Influence of the incubation temperature, atmosphere and dynamic conditions on biofilm formation by Salmonella spp. Food Microbiol. 2003; 20(3):339- 343.

42. Streulens MJ, De Ryck R,DeplanoA. Analysis of microbial genomic macrorestriction patterns by pulse-field gel electrophoresis (PFGE) typing. In: Dijkshoorn L, Towner KJ, StrulensM, editors. New approaches for the generation and analysis of microbial typing data. Amsterdam: Elsevier Science B.V; 2001. p. 159-176. 
43. Voss-Rech D, Vaz CSL, Alves L, Coldebella A, LeãoJA,Rodrigues DP, Back AA. Temporal study of Salmonella enterica serotypes from broiler farms in Brazil. PoultSci. 2015; 94(3):433-444.

44. Whang YP, Li L, Shen JZ, Yang FJ, Wu YN. Quinolone-resistance in Salmonella is associated with decreased mRNA expression of virulence genes invA and avrA, growth and intracellular invasion and survival. Vet microbiol.2009; 133(4):328-334.

45. Yoo AY, Yu JE, Yoo H, Lee TH, Lee WH, Oha JI, Kang HY. Role of sigma factor E in regulation of SalmonellaAgf expression. BiochemBiophysResCommun. 2013; 430(1):131-136.

46. Ziech RE, Perin AP, Lampugnani C, Sereno MJ, Viana C, Soares VM, Bersot L. Biofilm-producing ability and tolerance to industrial sanitizers in Salmonella spp. isolated from Brazilian poultry processing plants. LWT - Food Sci Technol. 2016; 68:85-90.

47. Zou M, Shivaramu K, Siddhartha T. Molecular characterization of Salmonella enterica serotype Enteritidis isolates from humans by antimicrobial resistance, virulence genes, and pulsed-field gel electrophoresis.FoodbornePathogDis. 2012; 9(3):232-238.

\section{Figures}




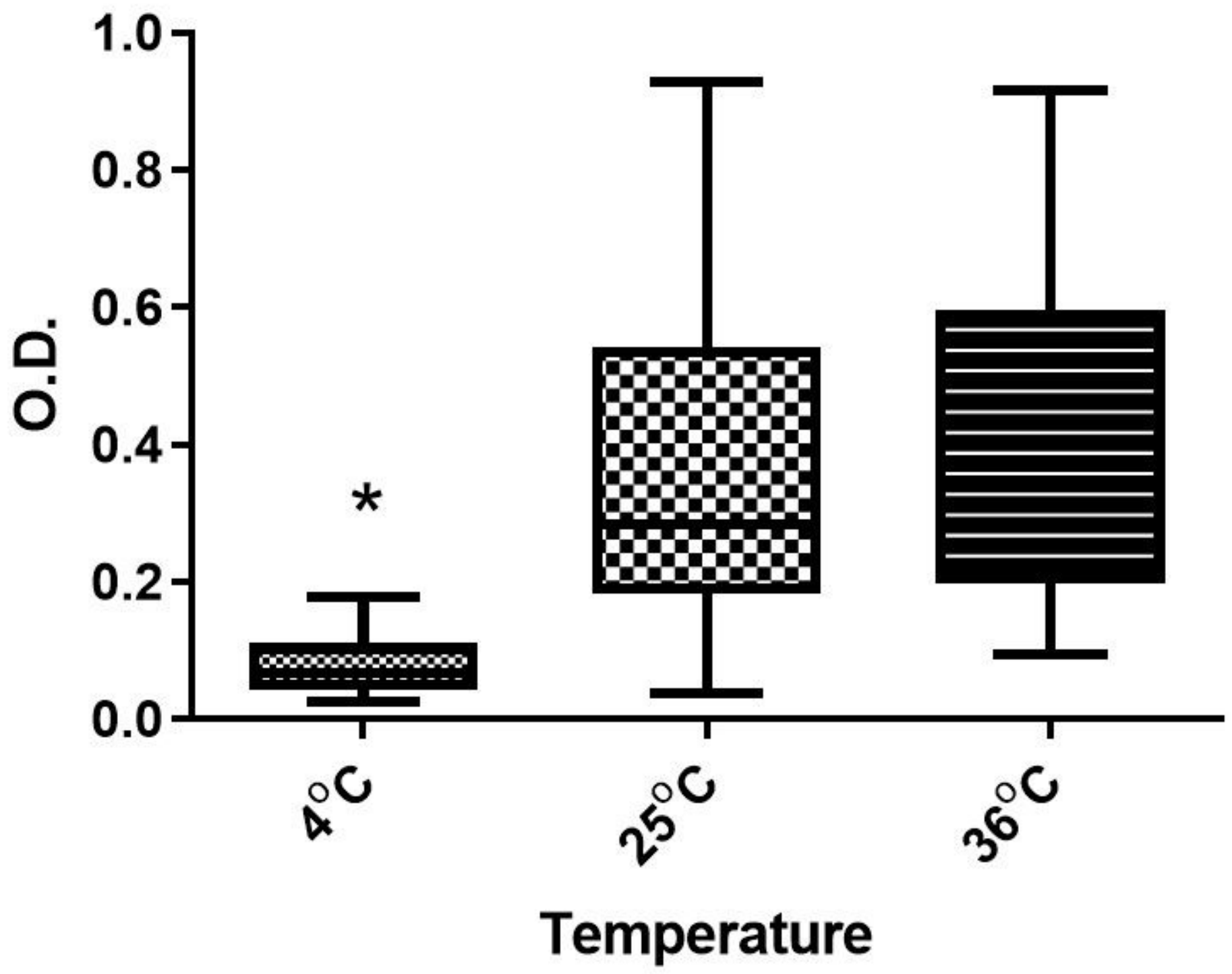

Figure 1

Biomass behavior of $20 \mathrm{~S}$. Minnesota strains at different temperatures O.D.: Optical density at $600 \mathrm{~nm}$. Error bars indicate the standard deviation for the mean OD values obtained for each strain; ${ }^{*} \mathrm{p}<0.001$ in comparative analysis between treatments using one way Anova. 


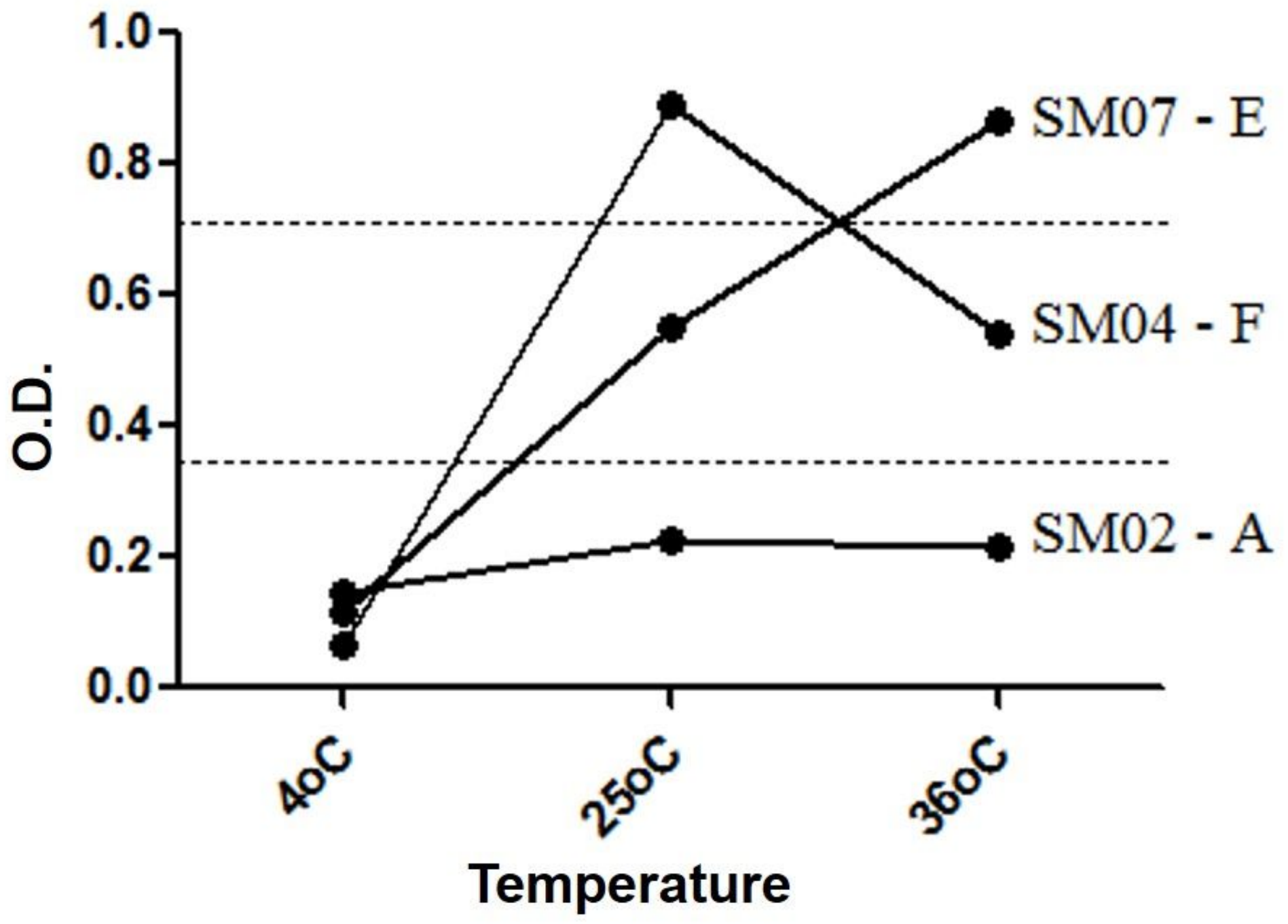

Figure 2

Biofilm biomass variation of three strains of S. Minnesota according to BFI profile O.D.: Optical density at 600nm. SM02, 04 and 07: Identification of Salmonella Minnesota strains. A, E and F: BFI Profiles (Table 2). -: Separation between nonexistent $(<0.35)$, weak $(0.35-0.69)$ and medium $(0.70-1.10)$ BFIs. 


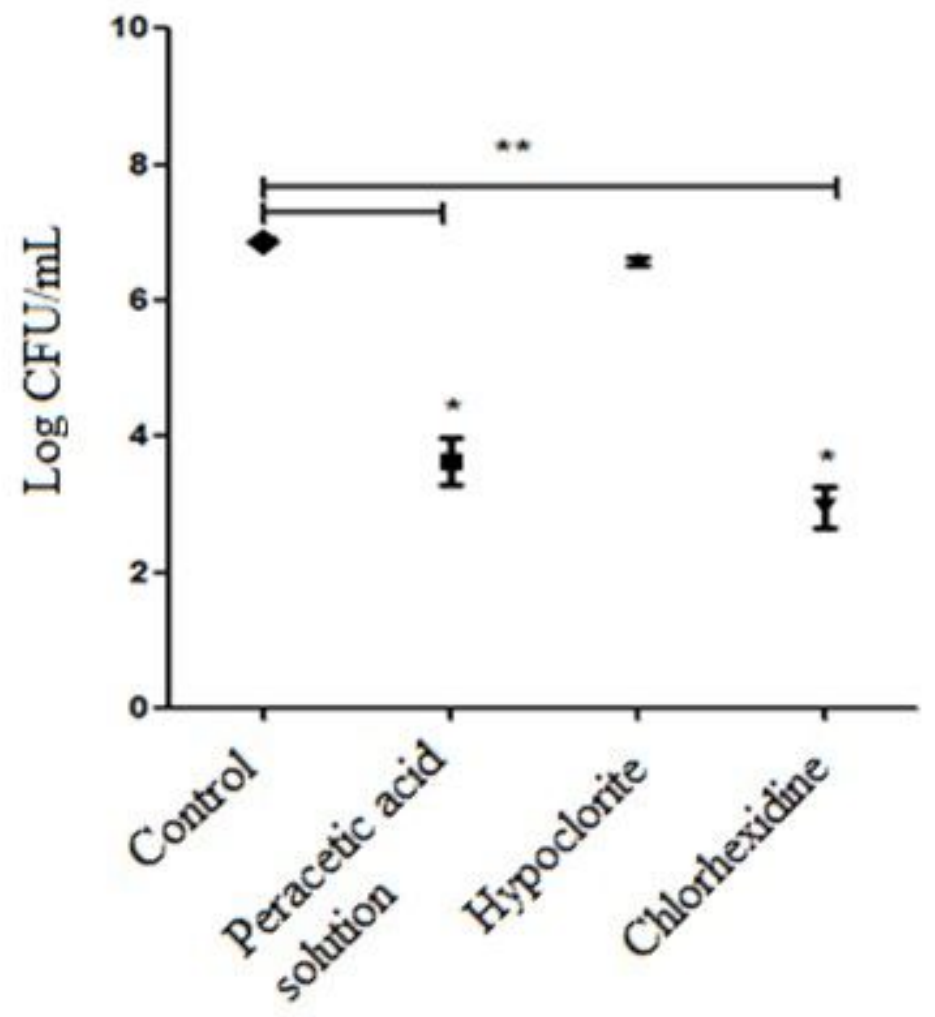

Figure 3

S. Minnesota biofilm counts (Log CFU/mL-1) before and after maintenance for 15 minutes in $0.8 \%$ peracetic acid solution, $1 \%$ sodium hypochlorite and $1 \%$ chlorhexidine. ${ }^{*} p<0.001$ for counts on samples from the same treatment; ${ }^{\star \star} p<0.001$ in the comparative analysis between control and treatments using Kruskal-Wallis. 


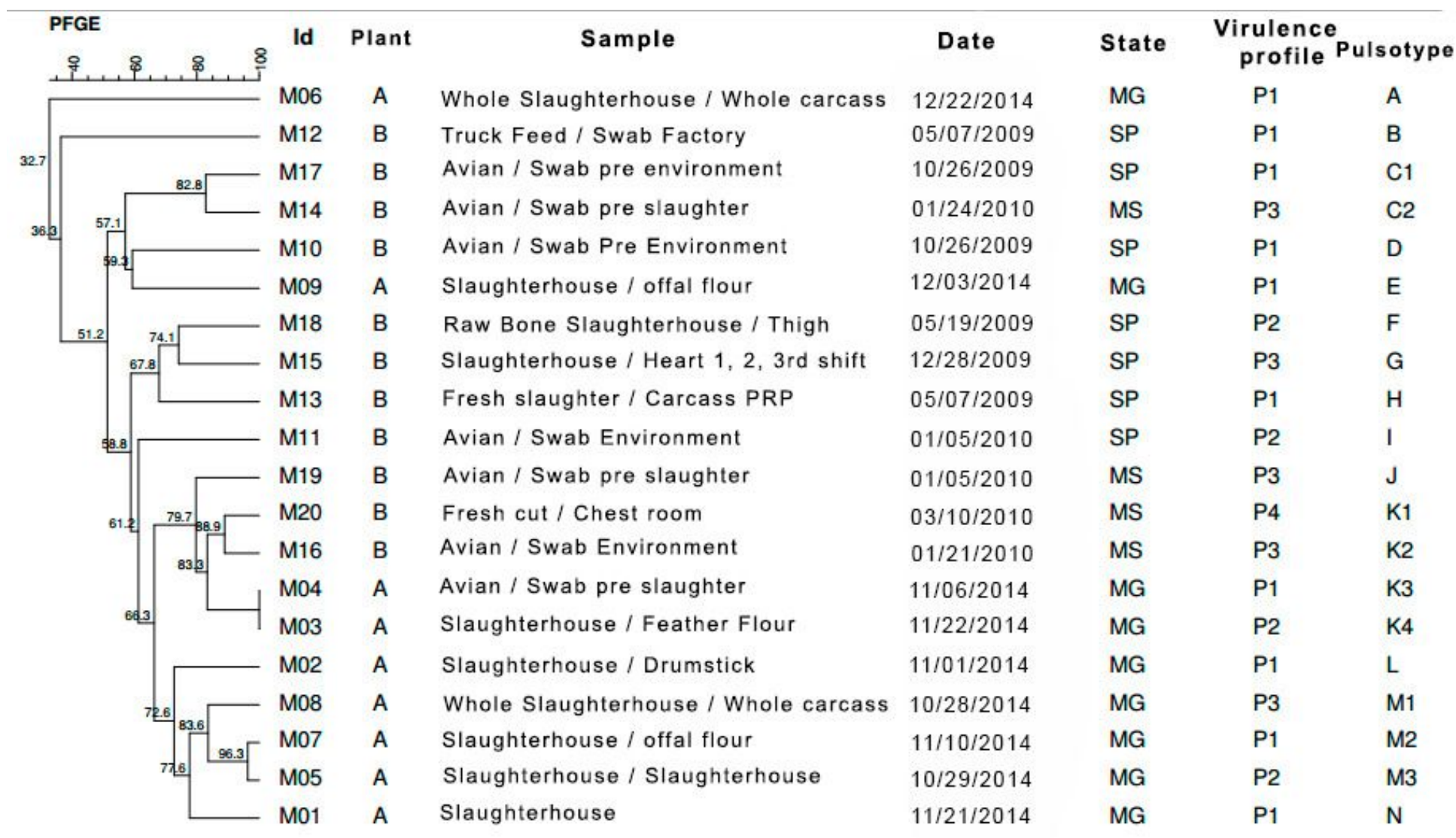

\section{Figure 4}

Comparative dendrogram of $20 \mathrm{~S}$. Minnesota strains, constructed from PFGE results considering the isolation site, date of collection, and the presence or absence of avrA, sodC, invA, agfA, IpfA and luxS genes using the Dice similarity coefficient with $1.5 \%$ tolerance and UPGMA method with $0.80 \%$ optimization. Presence of 14 pulsotypes (A to N) - three showed genotypic similarities above $80 \%$ "C", "K" and "M". 




Figure 5

SEM images for three strains of S. Minnesota submitted to temperatures of $4^{\circ} \mathrm{C}(5 \mathrm{a}), 25^{\circ} \mathrm{C}(5 \mathrm{~b})$ and $36^{\circ} \mathrm{C}$ (5c). 


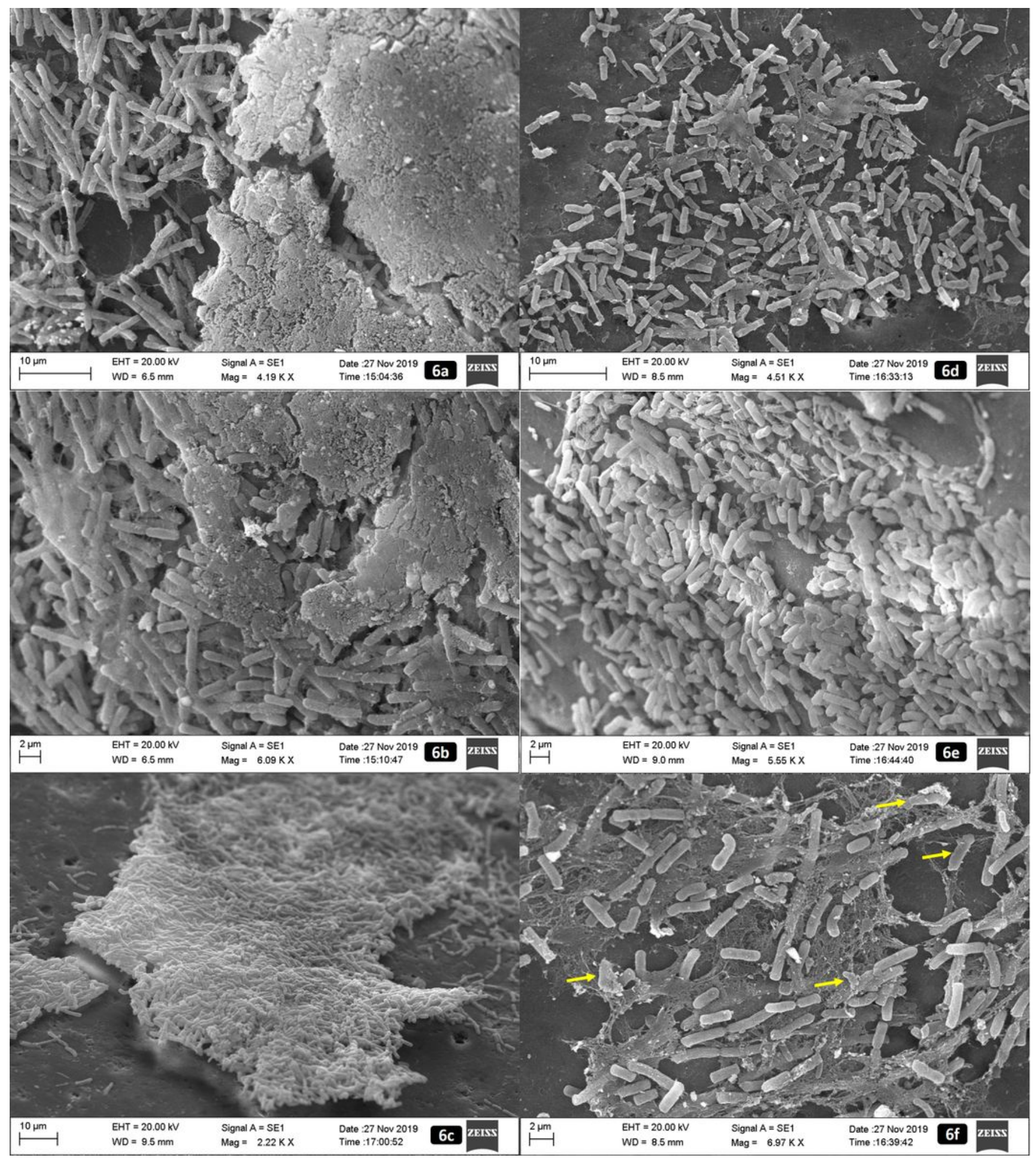

\section{Figure 6}

SEM images for three strains of S. Minnesota resistant after treatment with different sanitizing agents. 6a: negative control treated with water. $6 \mathrm{~b}$ : treatment with $1 \%$ sodium hypochlorite. $6 \mathrm{c}$ : maintenance of the structure of the mature biofilm after treatment with sodium hypochlorite $1 \%$. $6 \mathrm{~d}$ : treatment with $0.8 \%$ peracetic acid. $6 \mathrm{e}$ : treatment with $1 \%$ chlorhexidine. $6 \mathrm{f}$ (yellow arrows): morphological alteration and loss of membrane integrity in biofilm of S. Minnesota treated with $0.8 \%$ peracetic acid. 